\title{
Sugarcane Biochar as an Amendment for Greenhouse Growing Media for the Production of Cucurbit Seedlings
}

\author{
Charles L. Webber III ${ }^{1}$, Paul M. White Jr. ${ }^{1}$, Douglas J. Spaunhorst ${ }^{1}$, Isabel M. Lima ${ }^{2}$ \& Eric C. Petrie ${ }^{1}$ \\ ${ }^{1}$ USDA, Agriculture Research Service, Sugarcane Research Unit, Houma, LA, USA \\ ${ }^{2}$ USDA, Agriculture Research Service, New Orleans, LA, USA \\ Correspondence: Charles L. Webber III, USDA, Agriculture Research Service, Sugarcane Research Unit, Houma, \\ LA 70360, USA. E-mail: chuck.webber@ars.usda.gov
}

Received: November 16, 2017

Accepted: December 22, 2017

Online Published: January 15, 2018

doi:10.5539/jas.v10n2p104

URL: https://doi.org/10.5539/jas.v10n2p104

\begin{abstract}
Louisiana sugarcane farmers in 2016 harvested 11.7 million Mg millable sugarcane from 163,000 ha, producing 1.47 million $\mathrm{Mg}$ of raw sugar and an estimated 3.5 million $\mathrm{Mg}$ of bagasse. Even though Louisiana sugar mills use 80 to $90 \%$ of the bagasse for fuel production, another 350,000 to $700,000 \mathrm{Mg}$ of bagasse accumulates each year. The conversion of the excess bagasse into biochar is an excellent option with numerous uses. Research was conducted to determine the impact of sugarcane biochar as an amendment to soilless planting media for the production of cucurbit seedlings. Two biochars were combined by volume with a commercial certified organic soilless growing media into 5 combinations ( $0 \%: 100 \%, 25 \%: 75 \%, 50 \%: 50 \%, 75 \%: 25 \%$, and 100\%:0\%, biochars and growing media, respectively). Squash (Cucurbita pepo L.) var. 'Enterprise' and cantaloupe (Cucumis melo L.) var. 'Magnum .45 ' were planted in each of the 5 different planting mixtures. The higher heating value (HHV), lower heating value (LHV), and fixed carbon (FixC) were greater for the standard bagasse biochar (SBB), therefore, making it more valuable as a potential fuel source than the pneumatic bagasse biochar (PBB). All of the biochar mixture combinations compared favorably to the commercial media with low bulk densities ( 0.11 to $0.14 \mathrm{~g} \mathrm{~cm}^{-3}$ ) and high water holding capacities (80-87\%). In respect to seedling production, the biochars (SBB and PBB) performed well, especially at the 25 and 50\% levels for both plant species. The squash seedlings responded better at the $75 \%$ level than the cantaloupe seedlings, which reflect differences in nutrient requirements. The $100 \%$ biochar growing media are not recommended because both plant species often had a decrease in organic matter. These results indicate that the volume of a standard soilless greenhouse growing media can be successfully extended by adding 25 to $50 \%$ sugarcane biochar without a reduction in squash and cantaloupe seedling production. Future research should investigate the impact of additional plant species, as well as different biochar sources on seedling production.
\end{abstract}

Keywords: agricultural by-products, bagasse, certified organic, soilless growing media, sugarcane

\section{Introduction}

Louisiana sugarcane farmers in 2016 harvested 11.7 million Mg millable sugarcane from 163,000 ha, producing 1.47 million $\mathrm{Mg}$ of raw sugar and an estimated 3.5 million Mg of bagasse (American Sugar Cane League, 2017). Global sugar production in 2016 was over 170 million $\mathrm{Mg}$ of raw sugar, which resulted in over $300 \mathrm{million} \mathrm{Mg}$ of bagasse (United States Department of Agriculture, 2017). Bagasse is the fibrous plant by-product remaining after removing the sucrose, water, and other extraneous material impurities (e.g. sediment) from the sugarcane brought to the mill. Bagasse, on dry weight basis, is composed of $40-50 \%$ cellulose, $30-35 \%$ hemicellulose, 20-30\% lignin, and a small percentage of other materials (Cardona et al., 2010; A. R. F. Drummond \& I. W. Drummond, 1996; Martin et al., 2007; Pandey et al., 2000; Sales \& Lima, 2010;). Sugarcane bagasse has been used for paper and fiber board production (Amin, 2011; Xin et al., 2002), cattle feed (Nigam, 1990; Pandey et al., 2000), potting media (Jhurree-Dussoruth et al., 2011; Trochoulias et al., 1990), a mulch for crop production (Webber et al., 2017a), a source for value added products (i.e. pigments, enzymes, amino acids, and drugs) (Pandey et al., 2000), and energy production (thermal conversion and ethanol) (Badger, 2002; Kilicaslan et al., 1999; Martin et al., 2007; Peng et al., 2009; Sun \& Cheng, 2002; ).

Louisiana sugarcane mills burn sugarcane bagasse to produce steam power to run equipment within the mill and/or as a boiler fuel for the clarification, evaporation, and crystallization processes. Although the composition 
of ash produced is dependent on the source of the sugarcane, bagasse ash content is predominately (60-81\%) silica dioxide $\left(\mathrm{SiO}_{2}\right)$ with low percentages of plant nutrients (Payá et al., 2002; Zandersons et al., 1999). Investigating the use of sugarcane bagasse ash as an amendment to soilless greenhouse growing media, it was determined that the amended media functioned well in many respects for the seedling production for squash, cantaloupe, bean (Phaseolus vulgaris L.), and Chinese kale (Brassica alboglabra). Unfortunatly, as the percentage of bagasse ash increased from 0 to $100 \%$ ash, the bulk densities also increased $\left(0.12\right.$ to $\left.71 \mathrm{~g} \mathrm{~cm}^{-3}\right)$, resulting in decrease in the physical growing media (Webber et al., 2016, 2017b).

Even after Louisiana sugar mills use 80 to $90 \%$ of the bagasse for fuel production (Hass \& Lima, 2017; Pandey et al., 2000) it results in 350,000 to $700,000 \mathrm{Mg}$ bagasse accumulation annually. The conversion of the excess bagasse into biochar is an excellent option with numerous uses. Biochar is the incomplete carbonization of organic material under limited oxygen (pyrolysis). Substantial research has been conducted concerning the impact of biochars and "slash and burn" practices on mineral soils with a much smaller quantity directed towards biochars as an amendment to soilless growing media (Barrett et al., 2016; Vaughn et al., 2013). In a research review of environmentally sustainable amendments for soilless growing media, 27 different organic materials were listed, including 4 amendments related to sugarcane waste (Barrett et al., 2016). The sugarcane waste materials included as amendments for soilless growing media were filtercake compost (Stoffella et al., 1996), sugarcane trash/sewage sludge compost (Jayasinghe et al., 2010), sugarcane bagasse ash (Webber et al., 2016), and sugarcane bagasse/manure vermicompost (Khomami \& Moharam, 2013). The three primary criteria for selecting amendments used in soilless growing media are performance, economics, and the increasing emphasis on the environmental impact (Barrett et al., 2016). The primary environmental concern is the identification of suitable alternatives to replace peat in soilless growing media due to several negative environmental impacts of peat harvesting (Alexander et al., 2008; Schmilewski, 2014). Vaughn et al. (2013) investigated the use of biochars from pelletized wood and wheat straw as a replacement (5 to 15\%) for peat in soilless growing media and determined that both biochars would be suitable replacements for peat at 5 to $15 \%$ rates.

The reported advantages of adding biochars to soils and soilless growing media include a greater ability to retain plant nutrients and reduce leaching of those nutrients, the addition of nutrients to the soil system, and decreasing the existing bulk densities, which increases aeration and root penetration (Laird, 2008; Vaughn et al., 2013; White et al., 2015). In contrast to sugarcane bagasse ash, adding biochar to a soilless growing media should provide a more ideal physical environment (Laird, 2008; Webber et al., 2016; 2017b). Although, in general, biochars have many characteristics in common, the plant material source and the preparation methods employed can greatly influence the properties and effectiveness when used as an amendment in soilless growing media (Vaughn et al., 2013).

In 2016, United State farmers harvested 162,000 ha of cucurbits (cucurbitaceae) with a value of 1.6 billion dollars (USDA, 2017). The value of the 14,690 ha of squash and 21,850 ha of cantaloupe harvested was worth 162.7 and 207.5 million dollars, respectively (USDA, 2017). Transplanted cucurbit seedlings can mature from 5 to 25 days earlier compared to the same varieties direct-seeded. As a result of the importance of these crops to the United States fresh market production, the environmental concern of harvesting peat moss, and the excess supply of sugarcane bagasse research was conducted to determine the impact of sugarcane bagasse biochar as an amendment to soilless planting media for the production of squash and cantaloupe seedlings.

\section{Material and Methods}

\subsection{Experimental Design}

The two biochars used in the greenhouse experiments were produced and provided by American Biocarbon LLC (White Castle, LA) using proprietary methods. American Biocarbon's torrefaction unit was used to convert the bagasse from the adjacent sugarcane mill (Cora Texas Manufacturing Co., White Castle, LA) into two different biochars. One biochar was produced using a pneumatic transport system while the other was not, but both were produced from sugarcane bagasse. The pneumatic bagasse biochar (PBB) and the standard bagasse biochar (SBB) were produced from sugarcane harvested in 2015 and transported in large tote bags to the USDA, ARS, Sugarcane Research Unit (Houma, LA) for storage inside until used. Both biochars were produced at $343^{\circ} \mathrm{C}$. The Cora Texas sugar mill is one of 11 sugarcane mills that together processed approximately 163,000 ha and 11.7 million $\mathrm{Mg}$ of Louisiana sugarcane in 2016 (American Sugar Cane League, 2017).

The PBB and SBB were combined by volume with a commercial growing media (Sunshine, Natural and Organic Professional Growing Mix, Sun Gro Horticulture Canada Ltd, Seba Beach, Canada) into 5 combinations (0:100\%, $25: 75 \%, 50: 50 \%, 75: 25 \%$, and 100:0\%, sugarcane bagasse biochar (PBB or SBB) and growing media, respectively) which served as experimental treatments. Each of the soilless media treatments were thoroughly 
mixed prior to placing the mixtures in Speedling ${ }^{\mathcal{O}}$ (Speedling Inc., Ruskin, FL) trays $(128$ cells, $67.6 \mathrm{~cm} \times 34.6 \mathrm{~cm}$ trays, cells: $3.1 \mathrm{~cm}$ square $\times 6.35 \mathrm{~cm}$ deep). The mixtures were moistened to facilitate the complete and consistent filling of each of the Speedling trays. The Speedling trays were then planted with either squash (Cucurbita pepo L.) var. 'Enterprise' (Otis S. Twilley Seed Co., Inc., Hodges, SC) or cantaloupe (Cucumis melo L.) var. 'Magnum .45' (Petoseed Co., Inc., Saticoy, CA). 'Enterprise' squash and 'Magnum .45' cantaloupe are high yielding hybrid cucurbit varieties that widely adaptive for production. 'Enterprise' matures in 41 days, and produces a yellow fruit, while. 'Magnum .45' produces a deep orange fruit, a small seed cavity and early fruit set (McCreight, 2017).

The squash and cantaloupe greenhouse experiments (USDA, ARS, Sugarcane Research Unit, Houma, LA) were repeated twice in the spring of 2016 for 20 days. The first squash and cantaloupe experiments were planted on May 6, 2016 and harvested on May 26, 2016. The second set of experiments was planted on June 2 and harvested on June 22, 2016. Each experiment included the 2 types of biochar (PBB and SBB) $\times 5$ soilless media mixtures $(0: 100 \%, 25: 75 \%, 50: 50 \%, 75: 25 \%$, and 100:0\%) $\times 4$ replications/experiment.

\subsection{Biochar Laboratory Analysis}

Proximate analyses for all samples were performed in triplicate by following American Society for Testing and Materials (ASTM) method D5142-09 using a thermo-gravimetric analyzer (TGA701, LECO, St. Joseph, MI). Moisture was determined as the weight loss after heating the sample under $\mathrm{N}_{2}$ atmosphere in open crucibles to $107{ }^{\circ} \mathrm{C}$ to stable sample weight. Volatile matter was determined as weight loss after heating sample under $\mathrm{N}_{2}$ atmosphere in covered crucibles to $950{ }^{\circ} \mathrm{C}$ for $7 \mathrm{~min}$. Ash was calculated from remaining mass after heating sample under $\mathrm{O}_{2}$ atmosphere in open crucibles to $750^{\circ} \mathrm{C}$ and holding to stable weight. Fixed carbon was calculated by difference.

Surface area measurements (duplicate samples) were obtained from nitrogen adsorption isotherms at $77^{\circ} \mathrm{K}$ using a Nova 2200e Surface Area Analyzer (Quantachrome Corp., Boynton Beach, FL). Specific surface areas (BET, Brunner-Emmett-Teller) were taken from adsorption isotherms using the BET equation. The micro pore size distributions were calculated using t-plots derived from the Nova 2200 software. A Thermo Orion $\mathrm{pH}$ meter (Beverly, MA) was used to measure $\mathrm{pH}$, where $1.0 \mathrm{~g}$ of sample was placed in $100 \mathrm{~mL}$ of deionized water, covered with Parafilm, and allowed to equilibrate by stirring at $300 \mathrm{rpm}$ for $48 \mathrm{~h}$ (duplicate samples).

\subsection{Physical Analysis of Biochar Amendment Combinations}

Each of the 5 soilless media mixtures were analyzed for bulk density $\left(\mathrm{g} \mathrm{cm}^{-3}\right)$, porosity $(\%)$, water saturation (\%), and water at field capacity (\%). Each physical test on the 5 soil media mixtures was repeated 4 times. The measuring chamber was a cylinder with a $40 \mathrm{~mm}$ inner diameter and an interior height of $64.5 \mathrm{~mm}$ with a measured volume of $81 \mathrm{~cm}^{3}$.

\subsection{Plant Growth and Analysis}

Five seedlings from the center of each tray were randomly harvested 20 days after planting the squash and cantaloupe. Each seedling was divided into above and below ground plant portions. Plant height was determined by measuring the distance from the media surface to the apical meristem. The upper portion of the plant was further divided into leaves and stalks. The plant roots were weighted after removing all planting media from root system. Fresh weight of the leaves, stalks, and roots was recorded. The plant portions were then oven dried for 2 days at $60{ }^{\circ} \mathrm{C}$ and then subsequently reweighed to determine dry weights. Plant establishment was determined at harvest by calculating the percentage of Speedling ${ }^{\circledR}$ planting cells containing viable seedlings. All data were subjected to ANOVA and mean separation using LSD with $\mathrm{P}=0.05$ (SAS Inc., SAS, Ver. 9.0, Cary, NC).

\section{Results and Discussion}

\subsection{Laboratory Analysis of Biochars}

The laboratory analysis determined that PBB moisture and ash content were at least twice as large, $(2.05 \times$ and $2.75 \times$, respectively), than what was obtained for the SBB material (Table 1). An increase in ash content typically will increase the biochar's bulk density and potential nutrient availability for seedling production (Table 1) (Webber et al., 2017b). The greater fixed carbon percentage increases the energy value (HHV and LHV) of the SBB compared to the PBB, and may influence the potential income streams for the two biochars (Table 1). 
Table 1 . Laboratory analysis of the two biochars for $\%$ moisture content (MC), $\%$ volatile matter (VOL), $\%$ fixed carbon (FixC), \% ash (ASH), higher heating value (HHV), lower heating value (LHV), and $\mathrm{pH}$

\begin{tabular}{|c|c|c|c|c|c|c|c|}
\hline Biochar & $\mathrm{MC}$ & VOL & FixC & Ash & HHV & LHV & $\mathrm{pH}$ \\
\hline & \multicolumn{6}{|c|}{ 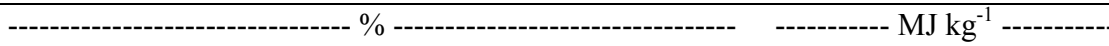 } & \\
\hline$\underline{\mathrm{SBB}}^{\mathrm{Z}}$ & $6.9 \pm 0.41$ & $44.0 \pm 1.00$ & $38.8 \pm 0.43$ & $17.2 \pm 1.13$ & $20.5 \pm 0.24$ & $19.0 \pm 0.23$ & $5.80 \pm 0.05$ \\
\hline$\underline{\mathrm{PBB}}^{\mathrm{Y}}$ & $14.2 \pm 0.73$ & $35.5 \pm 0.46$ & $17.7 \pm 0.17$ & $46.8 \pm 0.56$ & $14.4 \pm 0.12$ & $9.8 \pm 0.15$ & $6.05 \pm 0.05$ \\
\hline
\end{tabular}

Note. ${ }^{\mathrm{Z}} \mathrm{SBB}=$ Standard Bagasse Biochar produced by American Biocarbon LLC. ${ }^{\mathrm{Y}} \mathrm{PBB}=$ Pneumatic Bagasse Biochar produced by American Biocarbon LLC. Volatiles, fixed carbon, and ash in percent dry basis.

The particle size distribution analysis (Table 2) is in agreement with greater ash percentage for the PBB as reported in Table 1 . The $29 \%$ greater ash percentage for PPB (46.8\%) compared to SBB $(17.2 \%)$ is partially reflected in the shift in the particle size distribution between the two biochars (Tables 1 and 2). The SBB particle median, mean, geometric mean, and mode size were greater in all cases compared to the PBB values (Table 2).

Table 2. Laser scattering particle size distribution analysis (LA-950) of the two biochars (SBB and PBB) used as amendments to the greenhouse soilless growing media

\begin{tabular}{|c|c|c|c|c|}
\hline Biochar & Median & Mean & Geometric Mean & Mode \\
\hline & \multicolumn{4}{|c|}{ - } \\
\hline$\underline{\mathrm{SBB}}^{\mathrm{Z}}$ & 142.03 & 166.53 & 111.19 & 213.84 \\
\hline $\mathrm{PBB}^{\mathrm{Y}}$ & 101.15 & 123.81 & 88.36 & 162.80 \\
\hline
\end{tabular}

Note. ${ }^{\mathrm{Z}_{\mathrm{SBB}}}=$ Standard Bagasse Biochar produced by American Biocarbon LLC. ${ }^{\mathrm{P} B B}=$ Pneumatic Bagasse Biochar produced by American Biocarbon LLC. Volatiles, fixed carbon, and ash in percent dry basis.

\subsection{Physical Characteristics of the Media Mixtures}

The bulk densities of the media mixtures increased from $0.11 \mathrm{~g} \mathrm{~cm}^{-3}(0 \% \mathrm{SSB}$ and $0 \% \mathrm{PBB})$ to 0.14 and $0.13 \mathrm{~g}$ $\mathrm{cm}^{-3}$ for the 25 and $50 \% \mathrm{SBB}$, respectively, and to $0.13 \mathrm{~g} \mathrm{~cm}^{-3}$ for the $25 \%$ PBB (Table 3). The bulk densities then decreased from their highs at 25 and $50 \%$ levels as biochar content increased to $100 \%, 0.11 \mathrm{~g} \mathrm{~cm}^{-3}(\mathrm{SBB})$ and 0.11 $\mathrm{g} \mathrm{cm}^{-3}$ (PBB) (Table 3). These results are in contrast to similar research using the same mixture combinations with sugarcane bagasse ash instead of sugarcane biochar (Webber et al., 2017b). The bulk densities remained in an ideal range when the biochars were added, unlike earlier research where the addition of sugarcane bagasse ash increased bulk densities from 0.12 to $0.71 \mathrm{~g} \mathrm{~cm}^{-3}$ (Webber et al., 2017b). In contrast to Vaughn et al. (2013) who used biochar wood $\left(0.622 \mathrm{~g} \mathrm{~cm}^{-3}\right)$ and straw pellets $\left(0.238 \mathrm{~g} \mathrm{~cm}^{-3}\right)$ as a suitable replacement for peat at substitution rates of $5-15 \%$, the sugarcane bagasse biochars (SBB and PBB) bulk densities were $0.11 \mathrm{~g} \mathrm{~cm}^{-3}$ (Table 3). The bagasse biochars (SBB and PBB) bulk densities were not different from the commercial soilless growing media used in the research (Table 3) and comparable to the bulk density of peat, $0.157 \mathrm{~g} \mathrm{~cm}^{-3}$, measured by Vaughn et al. (2013). The lower bulk density values of the bagasse biochars maintained bulk densities in a suitable range as the biochar content increased from 0 to $100 \%$ of the growing media (Table 3 ).

As the biochar percentage increased in the media mixtures, the pore space, water saturation, and water at field capacity percentages tended to peak at 100\% PBB and were inconsistent with the SBB (Table 3). The pore space, water saturation, and water field capacity values for all mixture combinations for both biochars were at adequate levels to provide sufficient water availability to young seedlings. This is in contrast to research with sugarcane bagasse ash where the porosity, water saturation, and water at field capacity decreased significantly as the percentage of ash increased in the greenhouse growing mixtures (Webber et al., 2017b). 
Table 3. Impact of sugarcane biochar percentage as an amendment to greenhouse growing media on bulk density $\left(\mathrm{g} \mathrm{cm}^{-3}\right)$, percent total pore space, percent water saturation, and percent water at field capacity

\begin{tabular}{|c|c|c|c|c|}
\hline Composition $^{\mathrm{Z}}$ & Bulk Density & Pore Space & Water Saturation & Water at Field Capacity \\
\hline & ------ $\mathrm{g} \mathrm{cm}^{-3}$------ & --------------. & ---------- \% ---- & 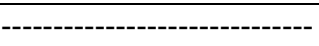 \\
\hline \multicolumn{5}{|l|}{$\underline{\mathrm{SBB}}^{\mathrm{Y}}$} \\
\hline $0 \%$ & $0.11 \mathrm{~d}^{\mathrm{W}}$ & $71.18 \mathrm{~d}$ & $86.49 \mathrm{~b}$ & 84.35 bcd \\
\hline $25 \%$ & $0.14 \mathrm{a}$ & $76.79 \mathrm{bc}$ & $84.92 \mathrm{~cd}$ & $79.64 \mathrm{e}$ \\
\hline $50 \%$ & $0.13 \mathrm{ab}$ & $71.47 \mathrm{~d}$ & $84.96 \mathrm{~cd}$ & $83.48 \mathrm{~d}$ \\
\hline $75 \%$ & $0.12 \mathrm{~cd}$ & $73.13 \mathrm{~cd}$ & $86.28 \mathrm{~b}$ & $84.34 \mathrm{bcd}$ \\
\hline $100 \%$ & $0.11 \mathrm{~d}$ & $73.80 \mathrm{~cd}$ & $86.92 \mathrm{ab}$ & $85.28 \mathrm{abc}$ \\
\hline \multicolumn{5}{|l|}{$\mathrm{PBB}^{\mathrm{X}}$} \\
\hline $0 \%$ & $0.11 \mathrm{~d}$ & $71.18 \mathrm{~d}$ & $86.49 \mathrm{~b}$ & 84.35 bcd \\
\hline $25 \%$ & $0.13 \mathrm{ab}$ & $72.17 \mathrm{~cd}$ & $84.57 \mathrm{~d}$ & $83.53 \mathrm{~cd}$ \\
\hline $50 \%$ & $0.12 \mathrm{bc}$ & $76.28 \mathrm{bc}$ & $85.00 \mathrm{bc}$ & $84.73 \mathrm{bcd}$ \\
\hline $75 \%$ & $0.12 \mathrm{~cd}$ & $79.80 \mathrm{ab}$ & $87.15 \mathrm{ab}$ & $85.79 \mathrm{ab}$ \\
\hline $100 \%$ & $0.11 \mathrm{~d}$ & $82.14 \mathrm{a}$ & $88.21 \mathrm{a}$ & $86.62 \mathrm{a}$ \\
\hline
\end{tabular}

Note. ${ }^{\mathrm{Z}}$ Percentage of sugarcane biochar in the growth medium based on volume; ${ }^{\mathrm{Y}} \mathrm{SBB}=\mathrm{Standard}$ Bagasse Biochar produced by American Biocarbon LLC. ${ }^{\mathrm{X}} \mathrm{PBB}=$ Pneumatic Bagasse Biochar produced by American Biocarbon LLC. ${ }^{\mathrm{W}}$ Means in a column followed by the same lower case letter are not significantly different at $\mathrm{P}=$ 0.05 , ANOVA.

\subsection{Seedling Analysis}

\subsubsection{Squash}

\section{(1) Squash Seedling Fresh and Dry Weights}

The squash fresh weights were consistent across experiments with no significant experiment $\times$ biochar treatment interactions at the $\mathrm{P}=0.05$ level (Table 4), therefore, the squash fresh weights will be discussed averaged across experiments (Table 5).

Table 4. Analysis of variance (ANOVA) for squash fresh and dry weights for source factors experiments, treatments, and experiment $\times$ treatment

\begin{tabular}{|c|c|c|c|c|c|}
\hline \multirow{2}{*}{ Source } & \multicolumn{5}{|c|}{ Squash Seedling Fresh Weights } \\
\hline & Stalk & Leaves & Tops & Roots & Total \\
\hline & $\operatorname{Pr}>F$ & $\operatorname{Pr}>F$ & $\operatorname{Pr}>\mathrm{F}$ & $\operatorname{Pr}>F$ & $\operatorname{Pr}>F$ \\
\hline Experiment & $<.0001$ & 0.0005 & $0.0633^{Z}$ & $<.0001$ & 0.0131 \\
\hline Treatment & $0.0025^{Z}$ & 0.0053 & 0.0021 & $0.0668^{\mathrm{Z}}$ & 0.0041 \\
\hline Experiment $\times$ Treatment & $0.1651^{\mathrm{Z}}$ & $0.9948^{Z}$ & $0.9225^{\mathrm{Z}}$ & $0.2205^{\mathrm{Z}}$ & $0.9117^{\mathrm{Z}}$ \\
\hline \multirow{3}{*}{ Source } & \multicolumn{5}{|c|}{ Squash Seedling Dry Weights } \\
\hline & Stalk & Leaves & Tops & Roots & Total \\
\hline & $\operatorname{Pr}>F$ & $\operatorname{Pr}>F$ & $\operatorname{Pr}>F$ & $\operatorname{Pr}>F$ & $\operatorname{Pr}>F$ \\
\hline Experiment & $<.0001$ & $0.8879^{\mathrm{Z}}$ & 0.0027 & $<.0001$ & $<.0001$ \\
\hline Treatment & 0.0040 & 0.0017 & 0.0010 & 0.0094 & 0.0017 \\
\hline Experiment $\times$ Treatment & $0.4903^{\mathrm{Z}}$ & $0.9354^{Z}$ & $0.9803^{\mathrm{Z}}$ & 0.0114 & $0.9826^{\mathrm{Z}}$ \\
\hline
\end{tabular}

Note. ${ }^{\mathrm{Z}}$ Not Significantly Different at $\mathrm{P}=0.05$, PROC ANOVA.

Squash fresh weights peaked at 25\% SBB and 50\% PBB, except for the SBB fresh root weights which were the greatest at $100 \%$ SBB (Table 5). Although the 25\% SBB was numerically better that the $0 \%$ SBB, except for the root values, the weights were not significantly different, an indication there was not a significant advantage of adding the SBB, but also not a disadvantage at $25 \%$ SBB. In all cases, the 50 and $75 \%$ SBB was as productive as the $0 \%$ control. The PBB fresh weights peaked at the mid ranges $(25 \%-75 \%)$, but tended to also drop off at the highest PBB level, 100\%, with the roots again being the exception. 
Table 5. Impact of sugarcane biochar percentages on squash seedling fresh weights (stalks, leaves, tops, roots, and total plant) averaged across two experiments, four replications per experiment, and five seedlings per replication

\begin{tabular}{|c|c|c|c|c|c|}
\hline \multirow{2}{*}{ Biochar $^{\text {Z }}$} & \multicolumn{5}{|c|}{ Squash Seedling Fresh Weights } \\
\hline & Stalk & Leaves & Tops & Roots & Total \\
\hline \multicolumn{6}{|l|}{$\underline{\mathrm{SBB}}^{\mathrm{Y}}$} \\
\hline $0 \%$ & $3.64 \mathrm{abc}^{\mathrm{W}}$ & $10.87 \mathrm{bc}$ & $14.51 \mathrm{~b}$ & $0.88 \mathrm{bc}$ & $15.39 \mathrm{~b}$ \\
\hline $25 \%$ & $3.80 \mathrm{abc}$ & $11.42 \mathrm{ab}$ & $15.22 \mathrm{ab}$ & $0.82 \mathrm{c}$ & $16.04 \mathrm{ab}$ \\
\hline $50 \%$ & $3.47 \mathrm{bc}$ & $10.76 \mathrm{bc}$ & $14.23 \mathrm{bc}$ & $0.91 \mathrm{bc}$ & $15.13 \mathrm{bc}$ \\
\hline $75 \%$ & $3.52 \mathrm{bc}$ & $11.00 \mathrm{~b}$ & $14.52 \mathrm{~b}$ & $0.90 \mathrm{bc}$ & $15.43 \mathrm{~b}$ \\
\hline $100 \%$ & $2.96 \mathrm{~d}$ & $9.94 \mathrm{c}$ & $12.90 \mathrm{c}$ & $0.99 \mathrm{ab}$ & $13.89 \mathrm{c}$ \\
\hline \multicolumn{6}{|l|}{${\underline{\mathrm{PBB}^{\mathrm{X}}}}^{-}$} \\
\hline $0 \%$ & $3.64 \mathrm{abc}$ & $10.87 \mathrm{bc}$ & $14.51 \mathrm{~b}$ & $0.88 \mathrm{bc}$ & $15.39 \mathrm{~b}$ \\
\hline $25 \%$ & $3.82 \mathrm{ab}$ & $11.31 \mathrm{ab}$ & $15.14 \mathrm{ab}$ & $0.88 \mathrm{bc}$ & $16.02 \mathrm{ab}$ \\
\hline $50 \%$ & $4.02 \mathrm{a}$ & $12.24 \mathrm{a}$ & $16.26 \mathrm{a}$ & $1.04 \mathrm{a}$ & $17.30 \mathrm{a}$ \\
\hline $75 \%$ & $3.56 \mathrm{bc}$ & $11.61 \mathrm{~b}$ & $15.17 \mathrm{ab}$ & $0.88 \mathrm{bc}$ & $16.05 \mathrm{ab}$ \\
\hline $100 \%$ & $3.36 \mathrm{dc}$ & $10.58 \mathrm{bc}$ & $13.94 \mathrm{bc}$ & $0.95 \mathrm{ab}$ & $14.90 \mathrm{bc}$ \\
\hline
\end{tabular}

Note. ${ }^{\mathrm{Z}}$ Percentage of sugarcane biochar in the growth medium based on volume; ${ }^{\mathrm{Y}} \mathrm{SBB}=\mathrm{Standard}$ Bagasse Biochar produced by American Biocarbon LLC. ${ }^{\mathrm{X}} \mathrm{PBB}=$ Pneumatic Bagasse Biochar produced by American Biocarbon LLC. ${ }^{\mathrm{W}}$ Means in a column followed by the same lower case letter are not significantly different at $\mathrm{P}=$ 0.05 , ANOVA.

Except for root dry weights, there were no significant experiment $\times$ biochar treatment interactions $(\mathrm{P}=0.05)$ (Table 4) for the squash seedling dry weights, therefore, all the squash dry weight data other than the dry root data will be discussed across experiments (Table 6).

Squash seedling dry weights (Table 6) were not as consistent as the squash fresh weights (Table 5) across the two biochars and the media combinations (Tables 5 and 6). A single media combination did not predominate across a specific plant portion, but there was a significant experiment $\times$ biochar interaction for dry root weights (Table 4). In general, the PBB mixtures percentages (25-100\%) had numerically greater dry weights compared to their corresponding SBB mixtures, but not consistently significantly greater. The stalk dry weights were consistent for the $25-75 \%$ SBB, but dropped off at the $100 \%$ SBB (Table 6). A similar pattern was seen with the leaves, tops, and total plant weights for $100 \% \mathrm{SBB}$, an indication that $100 \% \mathrm{SBB}$ is not advisable for squash seedling production (Table 6). Except for dry roots in experiment 1, the SBB plant dry weights for the $25-75 \%$ SSB media combinations were either numerically or significantly greater than the $0 \% \mathrm{SBB}$ (commercial growing media) values (Table 6). Except for the PBB root dry weights in experiment 2, the 50\% PBB treatment was either significantly or numerically greater than the other PBB percentages (Table 6). The 50\% PBB treatment was also typically greater than SBB plant dry weights (Table 6). This data suggests that $50 \%$ PBB media combination performed at a high production level and outperforming the commercial growing media. 
Table 6. Impact of sugarcane biochar percentages on squash seedling dry weights (stalks, leaves, tops, roots, and total plant) for two experiments, four replications per experiment, and five seedlings per replication

\begin{tabular}{|c|c|c|c|c|c|c|c|}
\hline \multirow{2}{*}{ Biochar $^{Z}$} & \multicolumn{7}{|c|}{ Squash Seedling Dry Weights } \\
\hline & Stalk & Leaves & \multicolumn{2}{|c|}{ Tops } & Roots \#1 & \multirow[t]{2}{*}{ Roots \#2 } & \multirow[t]{2}{*}{ Total } \\
\hline & ----- & & & & $\sigma_{-}-{ }_{-1}$ & & \\
\hline \multicolumn{8}{|l|}{$\underline{\mathrm{SBB}}^{\mathrm{Y}}$} \\
\hline $0 \%$ & $0.40 \mathrm{~cd}^{\mathrm{W}}$ & $1.16 \mathrm{~b}$ & 1.56 & $\mathrm{~b}$ & $0.28 \mathrm{ab}$ & $0.21 \mathrm{~cd}$ & $1.80 \mathrm{bc}$ \\
\hline $25 \%$ & $0.46 \mathrm{bcd}$ & $1.25 \mathrm{ab}$ & 1.71 & $a b$ & $0.23 \mathrm{c}$ & $0.22 \mathrm{bcd}$ & $1.93 \mathrm{~b}$ \\
\hline $50 \%$ & $0.47 \mathrm{abc}$ & $1.18 \mathrm{~b}$ & 1.64 & $\mathrm{~b}$ & $0.27 \mathrm{bc}$ & $0.20 \mathrm{~d}$ & $1.87 \mathrm{~b}$ \\
\hline $75 \%$ & $0.46 \mathrm{abc}$ & $1.20 \mathrm{ab}$ & 1.66 & $\mathrm{~b}$ & $0.26 \mathrm{bc}$ & $0.22 \mathrm{bcd}$ & $1.90 \mathrm{~b}$ \\
\hline $100 \%$ & $0.39 \mathrm{~d}$ & $0.93 \mathrm{c}$ & 1.32 & $\mathrm{c}$ & $0.24 \mathrm{bc}$ & $0.25 \mathrm{a}$ & $1.57 \mathrm{c}$ \\
\hline \multicolumn{8}{|l|}{$\mathrm{PBB}^{-}$} \\
\hline $0 \%$ & $0.40 \mathrm{~cd}$ & $1.16 \mathrm{~b}$ & 1.56 & $\mathrm{~b}$ & $0.28 \mathrm{ab}$ & $0.21 \mathrm{~cd}$ & $1.80 \mathrm{bc}$ \\
\hline $25 \%$ & $0.50 \mathrm{ab}$ & $1.27 \mathrm{ab}$ & 1.77 & $a b$ & $0.26 \mathrm{bc}$ & $0.22 \mathrm{bcd}$ & $2.01 \mathrm{ab}$ \\
\hline $50 \%$ & $0.53 \mathrm{a}$ & $1.37 \mathrm{a}$ & 1.90 & $\mathrm{a}$ & $0.32 \mathrm{a}$ & $0.25 \mathrm{ab}$ & $2.18 \mathrm{a}$ \\
\hline $75 \%$ & $0.50 \mathrm{ab}$ & $1.29 \mathrm{ab}$ & 1.78 & $a b$ & $0.24 \mathrm{bc}$ & $0.23 \mathrm{abc}$ & $2.02 \mathrm{ab}$ \\
\hline $100 \%$ & $0.47 \mathrm{ab}$ & $1.14 \mathrm{~b}$ & 1.61 & $\mathrm{~b}$ & $0.26 \mathrm{bc}$ & $0.26 \mathrm{a}$ & $1.87 \mathrm{~b}$ \\
\hline
\end{tabular}

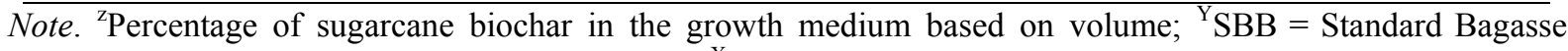
Biochar produced by American Biocarbon LLC. ${ }^{\mathrm{X}} \mathrm{PBB}=$ Pneumatic Bagasse Biochar produced by American Biocarbon LLC. ${ }^{\mathrm{W}}$ Means in a column followed by the same lower case letter are not significantly different at $\mathrm{P}=$ 0.05 , ANOVA.

\section{(2) Squash Seedling Height and Establishment}

Although there was not a significant $(\mathrm{P}=0.05)$ experiment $\times$ treatment interaction for squash seedling height (Table 7), the squash seedling establishment did reveal an experiment $\times$ treatment interaction (Table 7), therefore the squash seedling height will be discussed averaged across experiments (Table 8), while the squash seedling establishment will be discussed by experiment (Table 8).

Table 7. Analysis of variance (ANOVA) for squash seedling height and seedling establishment source factors; experiments, treatments, and experiment $\times$ treatment

\begin{tabular}{lll}
\hline Source & Height & Seedling Establishment \\
\hline & $\operatorname{Pr}>\mathrm{F}$ & $\operatorname{Pr}>\mathrm{F}$ \\
Experiment & $<.0001$ & 0.0093 \\
Treatment & $0.0925^{\mathrm{Z}}$ & 0.0009 \\
Experiment $\times$ Treatment & $0.4955^{\mathrm{Z}}$ & 0.0114 \\
\hline
\end{tabular}

Note. ${ }^{\mathrm{Z}}$ Not significantly different at $\mathrm{P}=0.05$, PROC ANOVA.

SBB and PBB percentages made very little difference in plant heights, except with a slight advantage for the 50\% PBB (Table 8). Plant establishment values were excellent for Experiment 1 and 2, typically at the 95\% level or greater, but there was a significant reduction in plant establishment for the $100 \% \mathrm{SBB}$ and PBB mixtures, $93.36 \%$ and $94.92 \%$, respectively (Table 8 ). 
Table 8. Impact of sugarcane biochar percentages on squash seedling height and establishment

\begin{tabular}{|c|c|c|c|c|c|}
\hline \multirow{2}{*}{ Biochar $^{Z}$} & \multicolumn{5}{|c|}{ Seedling Establishment } \\
\hline & Height & \multicolumn{2}{|c|}{ Exp. \#1 } & \multicolumn{2}{|c|}{ Exp. \#2 } \\
\hline${\underline{\mathrm{SBB}^{\mathrm{Y}}}}$ & 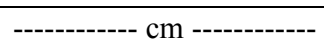 & -------- & - & -------- & 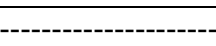 \\
\hline$\overline{0 \%}$ & $5.65 \mathrm{bc}^{\mathrm{W}}$ & 98.44 & $\mathrm{a}$ & 98.05 & $\mathrm{a}$ \\
\hline $25 \%$ & $6.07 \mathrm{ab}$ & 100.00 & $\mathrm{a}$ & 96.48 & $a b$ \\
\hline $50 \%$ & $5.76 \mathrm{abc}$ & 99.22 & $\mathrm{a}$ & 97.27 & $a b$ \\
\hline $75 \%$ & $5.89 \mathrm{abc}$ & 98.05 & $a b$ & 98.05 & $\mathrm{a}$ \\
\hline $100 \%$ & $5.31 \mathrm{c}$ & 95.70 & $\mathrm{bc}$ & 94.92 & $\mathrm{~b}$ \\
\hline \multicolumn{6}{|l|}{${\underline{\mathrm{PBB}^{\mathrm{X}}}}^{\mathrm{X}^{-}}$} \\
\hline $0 \%$ & $5.65 \mathrm{bc}$ & 98.44 & $\mathrm{a}$ & 98.05 & $\mathrm{a}$ \\
\hline $25 \%$ & $5.99 \mathrm{ab}$ & 99.22 & $\mathrm{a}$ & 96.88 & $a b$ \\
\hline $50 \%$ & $6.33 \mathrm{a}$ & 99.22 & $\mathrm{a}$ & 96.09 & $a b$ \\
\hline $75 \%$ & $5.87 \mathrm{abc}$ & 97.66 & $a b$ & 96.09 & $\mathrm{ab}$ \\
\hline $100 \%$ & $5.61 \mathrm{bc}$ & 93.36 & $\mathrm{c}$ & 96.88 & $a b$ \\
\hline
\end{tabular}

Note. ${ }^{\mathrm{I}}$ Percentage of sugarcane biochar in the growth medium based on volume; ${ }^{\mathrm{Y}} \mathrm{SBB}=$ Standard Bagasse Biochar produced by American Biocarbon LLC. ${ }^{\mathrm{X}} \mathrm{PBB}=$ Pneumatic Bagasse Biochar produced by American Biocarbon LLC. ${ }^{\mathrm{W}}$ Means in a column followed by the same lower case letter are not significantly different at $\mathrm{P}=$ 0.05 , ANOVA.

\subsubsection{Cantaloupe}

(1) Cantaloupe Seedling Fresh and Dry Weights

Due to significant experiment $\times$ biochar treatment interactions (Tables 9), the cantaloupe fresh (Table 10) and dry weights (Table 11) will be discussed by experiment.

Table 9. Analysis of variance (ANOVA) for cantaloupe fresh and dry weights for source factors experiments, treatments, and experiment $\times$ treatment

\begin{tabular}{llllll}
\hline \multirow{2}{*}{ Source } & \multicolumn{5}{c}{ Cantaloupe Seedling Fresh Weights } \\
\cline { 2 - 5 } & Stalk & Leaves & Tops & Roots & Total \\
\hline \multirow{2}{*}{ Experiment } & $\operatorname{Pr}>\mathrm{F}$ & $\operatorname{Pr}>\mathrm{F}$ & $\operatorname{Pr}>\mathrm{F}$ & $\operatorname{Pr}>\mathrm{F}$ & $\operatorname{Pr}>\mathrm{F}$ \\
Treatment & $<.0001$ & $<.0001$ & $<.0001$ & $<.0001$ & $<.0001$ \\
Experiment $\times$ Treatment & $<.0001$ & $<.0001$ & $<.0001$ & $0.1611^{\mathrm{Z}}$ & $<.0001$ \\
\hline \multirow{2}{*}{ Source } & 0.0003 & 0.0007 & 0.0005 & $<.0001$ & 0.0004 \\
\hline \multirow{2}{*}{ Experiment } & \multicolumn{7}{c}{ Cantaloupe Seedling Dry Weights } & Total \\
Treatment & Stalk & Leaves & Tops & Roots & Pr $>\mathrm{F}$ \\
Experiment $\times$ Treatment & $\operatorname{Pr}>\mathrm{F}$ & $\operatorname{Pr}>\mathrm{F}$ & $\operatorname{Pr}>\mathrm{F}$ & $\operatorname{Pr}>\mathrm{F}$ & $<.0001$ \\
\hline
\end{tabular}

Note. ${ }^{\mathrm{Z}}$ Not significantly different at $\mathrm{P}=0.05$, PROC ANOVA.

Averaged across biochar treatments, experiment 2 had significantly greater fresh and dry weights than experiment 1 . The yield advantages for experiment 2 may be the result of additional heat units and solar radiation received due to the sequential nature of the experiments (experiment 1, May 6 to May 26, 2016, and experiment 2, June 2 to June 22, 2016). In experiment 1, the fresh weights for cantaloupe seedlings plant parts were numerically greater than their corresponding weights in experiment 1 , except for leaf and top weights at $100 \%$ SBB (Table 10). Only in 3 situations the cantaloupe dry weights in experiment 1 were greater than experiment 2; the leaves, tops, and total weights for $100 \%$ SBB (Table 11).

The cantaloupe fresh and dry weights in many respects were inconsistent by experiment and the biochar percentages they contained (Tables 10 and 11). Total fresh and dry weights were often not significantly different 
at the 0,25 , and $50 \%$ biochar levels, in contrast to $100 \%$ SBB and PBB treatments which were typically lower (Tables 10 and 11). These data suggest that the biochar percentage can be increased up to $50 \%$ as a growing media component without reducing cantaloupe seedling production, but 75 and $100 \%$ biochar should be avoided.

Table 10. Impact of sugarcane biochar percentage of growth medium on cantaloupe seedling fresh weights (stalk, leaves, tops, roots and total) two experiments, four replications per experiment, and five seedlings per replication

\begin{tabular}{|c|c|c|c|c|c|c|c|c|c|c|}
\hline \multirow{3}{*}{ Biochar $^{Z}$} & \multicolumn{10}{|c|}{ Cantaloupe Seedling Fresh Weights (Experiments 1 and 2) } \\
\hline & $\# 1$ & $\# 2$ & $\# 1$ & $\# 2$ & \#1 & \#2 & $\# 1$ & \#2 & $\# 1$ & $\# 2$ \\
\hline & Stalks & Stalks & Leaves & Leaves & Tops & Tops & Roots & Roots & Total & Total \\
\hline \multicolumn{11}{|l|}{$\underline{\mathrm{SBB}}^{\mathrm{Y}}$} \\
\hline$\overline{0 \%}$ & $0.53 \mathrm{bc}^{\mathrm{W}}$ & $1.15 \mathrm{a}$ & $2.36 \mathrm{bc}$ & $4.58 \mathrm{a}$ & $2.89 \mathrm{~cd}$ & $5.73 \mathrm{a}$ & $0.14 \mathrm{~d}$ & $0.42 \mathrm{~b}$ & $3.03 \mathrm{~cd}$ & $6.15 \mathrm{a}$ \\
\hline $25 \%$ & $0.78 \mathrm{a}$ & $1.11 \mathrm{a}$ & $3.17 \mathrm{a}$ & $4.61 \mathrm{a}$ & $3.95 \mathrm{a}$ & $5.72 \mathrm{a}$ & $0.17 \mathrm{bcd}$ & $0.49 \mathrm{a}$ & $4.12 \mathrm{a}$ & $6.21 \mathrm{a}$ \\
\hline $50 \%$ & $0.53 \mathrm{bc}$ & $1.17 \mathrm{a}$ & $2.24 \mathrm{~cd}$ & $4.25 \mathrm{a}$ & $2.77 \mathrm{~cd}$ & $5.42 \mathrm{a}$ & $0.21 \mathrm{ab}$ & $0.44 \mathrm{ab}$ & $2.98 \mathrm{~cd}$ & $5.86 \mathrm{a}$ \\
\hline $75 \%$ & $0.47 \mathrm{c}$ & $0.69 \mathrm{~b}$ & $2.16 \mathrm{~cd}$ & $2.87 \mathrm{bc}$ & $2.63 \mathrm{~cd}$ & $3.56 \mathrm{ab}$ & $0.20 \mathrm{abc}$ & $0.41 \mathrm{bc}$ & $2.83 \mathrm{~cd}$ & $3.97 \mathrm{bc}$ \\
\hline $100 \%$ & $0.41 \mathrm{c}$ & $0.47 \mathrm{~b}$ & $2.05 \mathrm{~d}$ & $1.98 \mathrm{c}$ & $2.47 \mathrm{~d}$ & $2.45 \mathrm{c}$ & $0.22 \mathrm{ab}$ & $0.39 \mathrm{bc}$ & $2.68 \mathrm{~d}$ & $2.84 \mathrm{c}$ \\
\hline \multicolumn{11}{|l|}{$\mathrm{PBB}^{\mathrm{X}^{-}}$} \\
\hline $0 \%$ & $0.53 \mathrm{bc}$ & $1.15 \mathrm{a}$ & $2.36 \mathrm{bc}$ & $4.58 \mathrm{a}$ & $2.89 \mathrm{~cd}$ & $5.73 \mathrm{a}$ & $0.14 \mathrm{~d}$ & $0.42 \mathrm{~b}$ & $3.03 \mathrm{~cd}$ & $6.15 \mathrm{a}$ \\
\hline $25 \%$ & $0.76 \mathrm{a}$ & $1.17 \mathrm{a}$ & $2.97 \mathrm{ab}$ & $4.52 \mathrm{a}$ & $3.73 \mathrm{ab}$ & $5.69 \mathrm{a}$ & $0.15 \mathrm{~d}$ & $0.46 \mathrm{ab}$ & $3.88 \mathrm{ab}$ & $6.15 \mathrm{a}$ \\
\hline $50 \%$ & $0.74 \mathrm{a}$ & $1.17 \mathrm{a}$ & $2.92 \mathrm{ab}$ & $4.16 \mathrm{a}$ & $3.66 \mathrm{ab}$ & $5.33 \mathrm{a}$ & $0.16 \mathrm{~cd}$ & $0.41 \mathrm{bc}$ & $3.82 \mathrm{ab}$ & $5.74 \mathrm{a}$ \\
\hline $75 \%$ & $0.65 \mathrm{ab}$ & $1.00 \mathrm{a}$ & $2.59 \mathrm{bc}$ & $3.73 \mathrm{ab}$ & $3.24 \mathrm{bc}$ & $4.73 \mathrm{ab}$ & $0.22 \mathrm{ab}$ & $0.42 \mathrm{ab}$ & $3.46 \mathrm{bc}$ & $5.15 \mathrm{ab}$ \\
\hline $100 \%$ & $0.48 \mathrm{c}$ & $0.53 \mathrm{~b}$ & $2.10 \mathrm{~d}$ & $2.18 \mathrm{c}$ & $2.58 \mathrm{~d}$ & $2.71 \mathrm{c}$ & $0.24 \mathrm{a}$ & $0.35 \mathrm{c}$ & $2.82 \mathrm{~cd}$ & $3.06 \mathrm{c}$ \\
\hline
\end{tabular}

Note. ${ }^{\mathrm{z}}$ Percentage of sugarcane biochar in the growth medium based on volume; ${ }^{\mathrm{Y}} \mathrm{SBB}=$ Standard Bagasse Biochar produced by American Biocarbon LLC. ${ }^{\mathrm{X}} \mathrm{PBB}=$ Pneumatic Bagasse Biochar produced by American Biocarbon LLC. ${ }^{\mathrm{W}}$ Means in a column followed by the same lower case letter are not significantly different at $\mathrm{P}=$ 0.05 , ANOVA.

Table 11. Impact of sugarcane biochar percentage of growth medium on cantaloupe seedling oven dry weights (stalk, leaves, tops, roots and total) for two experiments, four replications per experiment, and five seedlings per replication

\begin{tabular}{|c|c|c|c|c|c|c|c|c|c|c|}
\hline \multirow{3}{*}{ Biochar $^{Z}$} & \multicolumn{10}{|c|}{ Cantaloupe Seedling Dry Weights (Experiments 1 and 2) } \\
\hline & $\# 1$ & $\# 2$ & $\# 1$ & $\# 2$ & $\# 1$ & \#2 & \#1 & $\# 2$ & $\# 1$ & $\# 2$ \\
\hline & Stalks & Stalks & Leaves & Leaves & Tops & Tops & Roots & Roots & Total & Total \\
\hline & & & & & & & & & & \\
\hline \multicolumn{11}{|l|}{$\underline{\mathrm{SBB}}^{\mathrm{Y}}$} \\
\hline $0 \%$ & $0.11 \mathrm{bc}^{\mathrm{W}}$ & $0.23 \mathrm{a}$ & $0.37 \mathrm{~cd}$ & $0.67 \mathrm{ab}$ & $0.48 \mathrm{~cd}$ & $0.90 \mathrm{ab}$ & $0.06 \mathrm{e}$ & $0.14 \mathrm{~b}$ & 0.54 cde & $1.04 \mathrm{ab}$ \\
\hline $25 \%$ & $0.14 \mathrm{a}$ & $0.21 \mathrm{ab}$ & $0.50 \mathrm{a}$ & $0.73 \mathrm{a}$ & $0.64 \mathrm{a}$ & $0.94 \mathrm{a}$ & 0.07 cde & $0.17 \mathrm{a}$ & $0.71 \mathrm{a}$ & $1.11 \mathrm{a}$ \\
\hline $50 \%$ & $0.09 \mathrm{bc}$ & $0.22 a b$ & $0.37 \mathrm{~cd}$ & $0.64 \mathrm{ab}$ & 0.47 cde & $0.86 \mathrm{ab}$ & $0.08 \mathrm{bcd}$ & $0.15 \mathrm{ab}$ & 0.55 cde & $1.00 \mathrm{ab}$ \\
\hline $75 \%$ & $0.07 \mathrm{de}$ & $0.12 \mathrm{c}$ & $0.33 \mathrm{~d}$ & $0.44 \mathrm{~cd}$ & $0.40 \mathrm{de}$ & $0.56 \mathrm{~cd}$ & $0.08 \mathrm{bcd}$ & $0.13 \mathrm{bc}$ & $0.48 \mathrm{de}$ & $0.69 \mathrm{~cd}$ \\
\hline $100 \%$ & $0.07 \mathrm{e}$ & $0.07 \mathrm{~d}$ & $0.32 \mathrm{~d}$ & $0.28 \mathrm{e}$ & $0.38 \mathrm{e}$ & $0.35 \mathrm{e}$ & $0.09 \mathrm{ab}$ & $0.11 \mathrm{~d}$ & $0.48 \mathrm{e}$ & $0.46 \mathrm{e}$ \\
\hline \multicolumn{11}{|l|}{${\underline{\mathrm{PBB}^{\mathrm{X}}}}^{-1}$} \\
\hline $0 \%$ & $0.11 \mathrm{bc}$ & $0.23 \mathrm{a}$ & $0.37 \mathrm{~cd}$ & $0.67 \mathrm{ab}$ & $0.48 \mathrm{~cd}$ & $0.90 \mathrm{ab}$ & $0.06 \mathrm{e}$ & $0.14 \mathrm{~b}$ & $0.54 \mathrm{cde}$ & $1.04 \mathrm{ab}$ \\
\hline $25 \%$ & $0.14 \mathrm{a}$ & $0.23 \mathrm{a}$ & $0.49 \mathrm{a}$ & $0.72 \mathrm{a}$ & $0.64 \mathrm{a}$ & $0.95 \mathrm{a}$ & $0.06 \mathrm{e}$ & $0.15 \mathrm{ab}$ & $0.70 \mathrm{ab}$ & $1.10 \mathrm{ab}$ \\
\hline $50 \%$ & $0.13 \mathrm{ab}$ & $0.22 \mathrm{ab}$ & $0.45 \mathrm{ab}$ & $0.66 \mathrm{ab}$ & $0.58 \mathrm{ab}$ & $0.88 \mathrm{ab}$ & $0.06 \mathrm{de}$ & $0.14 \mathrm{~b}$ & $0.64 \mathrm{abc}$ & $1.02 \mathrm{ab}$ \\
\hline $75 \%$ & $0.10 \mathrm{bc}$ & $0.18 \mathrm{~b}$ & $0.40 \mathrm{bc}$ & $0.56 \mathrm{bc}$ & $0.50 \mathrm{bc}$ & $0.74 \mathrm{bc}$ & $0.09 \mathrm{abc}$ & $0.15 \mathrm{ab}$ & $0.59 \mathrm{bcd}$ & $0.89 \mathrm{bc}$ \\
\hline $100 \%$ & $0.07 \mathrm{e}$ & $0.08 \mathrm{~cd}$ & $0.31 \mathrm{~d}$ & $0.31 \mathrm{de}$ & $0.38 \mathrm{e}$ & $0.39 \mathrm{de}$ & $0.11 \mathrm{a}$ & $0.12 \mathrm{~cd}$ & $0.49 \mathrm{de}$ & $0.51 \mathrm{de}$ \\
\hline
\end{tabular}

Note. ${ }^{\mathrm{Z}}$ Percentage of sugarcane biochar in the growth medium based on volume; ${ }^{\mathrm{y}}$ Means in a column followed by the same lower case letter are not significantly different at $\mathrm{P}=0.05$, ANOVA. 
(2) Cantaloupe Seedling Height and Establishment

There was not a significant $(\mathrm{P}=0.05)$ experiment $\times$ treatment interaction for cantaloupe seedling height and seedling establishment (Table 12), therefore, the cantaloupe seedling height and seedling establishment will be discussed averaged across experiments (Table 13).

Table 12. Analysis of variance (ANOVA) for cantaloupe seedling height and seedling establishment source factors; experiments, treatments, and experiment $\times$ treatment

\begin{tabular}{lll}
\hline Source & Height & Seedling Establishment \\
\hline & $\operatorname{Pr}>\mathrm{F}$ & $\operatorname{Pr}>\mathrm{F}$ \\
Experiment & 0.0007 & $0.1818^{\mathrm{Z}}$ \\
Treatment & 0.0040 & $0.9899^{\mathrm{Z}}$ \\
Experiment $\times$ Treatment & $0.1026^{\mathrm{Z}}$ & $0.4966^{\mathrm{Z}}$ \\
\hline
\end{tabular}

Note. ${ }^{\mathrm{Z}}$ Not significantly different at $\mathrm{P}=0.05$, PROC ANOVA.

Cantaloupe seedling heights peaked at the $50 \%$ PBB, while there was no difference among the other PBB $\%$ or within the SBB treatments (Table 13). Numerically, there was a decreasing trend for plant heights for both biochars above the $50 \%$ amendment level; perhaps a reflection of the decrease in total plant weights at the $100 \%$ biochar levels (Tables 10 and 11). Cantaloupe seedling establishment was consistent across biochar and amendment percentages, averaging in the 95 to $96 \%$ range (Table 13 ).

Table 13. Impact of sugarcane biochar percentage on cantaloupe seedling height and seedling establishment averaged across 2 experiments

\begin{tabular}{lll}
\hline Biochar $^{\mathrm{Z}}$ & Height & Seedling Establishment \\
\hline$\underline{\mathrm{SBB}}^{\mathrm{Y}}$ & -1 & \\
$0 \%$ & $2.67 \mathrm{bc}$ & $96.1 \mathrm{a}$ \\
$25 \%$ & $2.73 \mathrm{bc}$ & $95.3 \mathrm{a}$ \\
$50 \%$ & $2.60 \mathrm{bc}$ & $96.1 \mathrm{a}$ \\
$75 \%$ & $2.14 \mathrm{bc}$ & $96.1 \mathrm{a}$ \\
$100 \%$ & $2.04 \mathrm{c}$ & $96.5 \mathrm{a}$ \\
\hline$\underline{\mathrm{PBB}}$ & & \\
$0 \%$ & $2.67 \mathrm{bc}$ & $96.1 \mathrm{a}$ \\
$25 \%$ & $2.81 \mathrm{~b}$ & $95.7 \mathrm{a}$ \\
$50 \%$ & $3.56 \mathrm{a}$ & $95.9 \mathrm{a}$ \\
$75 \%$ & $2.58 \mathrm{bc}$ & $96.7 \mathrm{a}$ \\
$100 \%$ & $2.12 \mathrm{bc}$ & $96.7 \mathrm{a}$ \\
\hline
\end{tabular}

Note. ${ }^{\mathrm{z}}$ Percentage of sugarcane biochar in the growth medium based on volume; ${ }^{\mathrm{Y}} \mathrm{SBB}=$ Standard Bagasse Biochar produced by American Biocarbon LLC. ${ }^{\mathrm{X}} \mathrm{PBB}=$ Pneumatic Bagasse Biochar produced by American.

\section{Conclusions}

When using biochars as amendments for growing media it is important to evaluate its various physicochemical properties. Biochars herein utilized were sourced from the same sugarcane bagasse but produced under slightly different conditions that resulted in different physical and chemical compositions. Although these differences may not be critical to all biochar uses, the information may be critical in understanding the potential applications of the biochars. The increase in ash content for the PBB would tend in increase the biochar's bulk density and potential nutrient availability for seedling production. The HHV, LHV, and fixed C were greater for the SBB, therefore, making it more valuable as a potential fuel source than the PBB. The physical analysis of the soilless media combinations were excellent, producing low bulk densities $\left(0.11\right.$ to $\left.0.14 \mathrm{~g} \mathrm{~cm}^{-3}\right)$ and high water holding capacities (80-87\%). 
As an amendment to the soilless greenhouse growing media, the biochars (SBB and PBB) functioned very well especially at the 25 and $50 \%$ levels across both plant species. The squash seedlings did respond better at the $75 \%$ level than did cantaloupe seedlings, which reflect differences in nutrient requirements. The $100 \%$ biochar growing media are not recommended because both plant species often had a decrease in organic matter. These results indicate that the volume of a standard soilless greenhouse growing media can be successfully extended by adding 25 to $50 \%$ sugarcane biochar without reducing cucurbit seedling production. This research did not include weekly supplemental fertilizer applications, which in future research may compensate for any differences in nutrient requirements. Besides the impact of supplemental fertilizer applications, future research is needed to evaluate different biochar sources for seedling production with additional plant species.

\section{References}

Alexander, P. D., Bragg, N. C., Meade, R., Padelopoulos, G., \& Watts, O. (2008). Peat in horticulture and conservation: The UK response to a changing world. Mires and Peat, 3, Article 8. Retrieved from $\mathrm{http}: / /$ mires-and-peat.net/pages/volumes/map03/map0308.php

American Sugar Cane League. (2017). The Louisiana sugarcane industry production data 1975-2016. Retrieved November 16, 2017, from http://amscl.org/Images/Interior/sugar\%20industry\%20pamphlet/industryproduc tiondata1975-2016.pdf

Amin, N. (2011). Use of bagasse ash in concrete and its impact on the strength and chloride resistivity. $J$. Mater. Civ. Eng., 23(5), 717-720. https://doi.org/10.1061/(ASCE)MT.1943-5533.0000227

Badger, P. C. (2002). Ethanol from cellulose: A general review. In J. Janick \& A. Whipkey (Eds.), Trends in new crops and new uses (pp. 17-21). ASHS Press, Alexandria, VA.

Barrett, G. E., Alexander, P. D., Robinson, J. S., \& Bragg, N. C. (2016). Achieving environmentally sustainable growing media for soilless plant cultivation systems-A review. Scientia Horticulturae, 212, 220-234. https://doi.org/10.1016/j.scienta.2016.09.030

Cardona, C. A., Quintero, J. A., \& Paz, I. C. (2010). Production of bioethanol from sugarcane bagasse: Status and perspectives. Bioresource Techn., 101(13), 4754-4766. https://doi.org/10.1016/j.biortech.2009.10.097

Drummond, A. R. F., \& Drummond, I. W. (1996). Pyrolysis of sugar cane bagasse in a wire-mesh reactor. Ind. Eng. Chem. Res., 35(4), 1263-1268. https://doi.org/10.1021/ie9503914

Hass, A., \& Lima, I. (2017). Effect of feed source and pyrolysis conditions on sugarcane bagasse biochar. Sugar Journal, $80(1), 31$.

Jayasinghe, G. Y., Tokashiki, Y., Arachchi, I. D. L., \& Arakaki, M. (2010). Sewage sludge sugarcane trash based compost and synthetic aggregates as peat substitutes in containerized media for crop production. J. Hazard. Mater., 174(1-3), 700-706. https://doi.org/10.1016/j.jhazmat.2009.09.107

Jhurree-Dussoruth, B., Kallydin, H., \& Bornes, Q. (2011). Investigation into low-cost medium for hardening of in vitro banana plantlets to promote adoption of disease-free plants. Acta Hort., 897, 489-490. https://doi.org/10.17660/ActaHortic.2011.897.69

Khomami, A. M., \& Moharam, M. G. (2013). Evaluation of sugar cane bagasse vermicompost as potting media on growth and nutrition of Dieffenbachia amoena 'tropic snow'. Int. J. Agron. Plant Prod., 4(8), 1806-1812.

Kilicaslan, I., Sarac, H. I., Ozdemir, E., \& Ermis, K. (1999). Sugar cane as an alternative energy source for Turkey. Energy Conversion and Management, 40(1), 1-11. https://doi.org/10.1016/S0196-8904(98)00103-4

Laird, D. A. (2008). The charcoal vision: A win-win-win scenario for simultaneously producing bioenergy, permanently sequestering carbon, while improving soil and water quality. Agronomy J., 100(1), 178-181. https://doi.org/10.2134/agronj2007.0161

Martin, C., Klinke, H. B., \& Thomsen, A. B. (2007). Wet oxidation as a pretreatment method for enhancing the enzymatic convertibility of sugarcane bagasse. Enzyme and Microbial Techn., 40:426-432. https://doi.org/ 10.1016/j.enzmictec.2006.07.015

McCreight, J. D. (2017). Vegetable Cultivar Descriptions for North America-Melon: Lists 1-27 Combined. Retrieved from http://cucurbitbreeding.com/todd-wehner/publications/vegetable-cultivar-descriptions-fornorth-america/melon/

Nigam, P. (1990). Investigation of some factors important for solid state fermentation of sugar cane bagasse for animal feed production. Enzyme and Microbial Techn., 12(10), 808-811. https://doi.org/10.1016/ 0141-0229(90)90156-K 
Pandey, A., Soccol, C. R., Nigam, P., \& Soccol, V. T. (2000). Biotechnological potential of agro-industrial residues. I: Sugarcane bagasse. Bioresource Technol., 74(1), 69-80. https://doi.org/10.1016/S0960-8524 (99)00142-X

Payá, J., Monzó, J., Borrachero, M. V., Díaz-Pinzón, L., \& Ordóňez, L. M. (2002). Sugar-cane bagasse ash (SCBA): Studies on its properties for reusing in concrete production. J. Chem Technol. Biotechnol., 77, 321-325. https://doi.org/10.1002/jctb.549

Peng, F., Ren, J. L., Xu, F., Bian, J., Peng, P., \& Sun, R. C. (2009). Comparative study of hemicelluloses obtained by graded ethanol precipitation from sugarcane bagasse. J. Agric. Food Chem., 57(14), 6305-6317. https://doi.org/10.1021/jf900986b

Sales, A., \& Lima, S. A. (2010). Use of Brazilian sugarcane bagasse ash in concrete as sand replacement. Waste Managemen, 30(6), 1114-1122. https://doi.org/10.1016/j.wasman.2010.01.026

Schmilewski, G. (2014). Producing growing media responsibly to help sustain horticulture. Acta Hortic., 1034(14), 299-305. https://doi.org/10.17660/ActaHortic.2014.1034.37

Stoffella, P. J., Li, Y., Calvert, D. V., \& Graetz, D. A. (1996). Soilless growing media amended with sugarcane filtercake compost for citrus rootstock production. Compost Sci. Util., 4(2), 21-25. https://doi.org/ 10.1080/1065657X.1996.10701826

Sun, Y., \& Cheng, J. (2002). Hydrolysis of lignocellulosic materials for ethanol production: A review. Bioresource Technol., 83(1), 1-11. https://doi.org/10.1016/S0960-8524(01)00212-7

Trochoulias, T., Burton, A. J., \& White, E. (1990). The use of bagasse as a potting medium for ornamentals. Scientia Horticulturae, 42(1-2), 161-167. https://doi.org/10.1016/0304-4238(90)90157-A

United States Department of Agriculture, Foreign Agricultural Service. (2017). Sugar: World markets and trade. Retrieved November 16, 2017, from https://apps.fas.usda.gov/psdonline/circulars/sugar.pdf

United States Department of Agriculture, National Agricultural Statistical Service. (2017). Vegetables 2016 Summary (February 2017, p. 111). Retrieved December 13, 2017, from http://usda.mannlib.cornell.edu/ usda/current/VegeSumm/VegeSumm-02-22-2017_revision.pdf

Vaughn, S. F., Kenar, J. A., Thompson, A. R., \& Peterson, S. C. (2013). Comparison of biochars derived from wood pellets and pelletized wheat straw as replacements for peat in potting substrates. Industrial Crops and Products, 51, 437-443. https://doi.org/10.1016/j.indcrop.2013.10.010

Webber, C. L. III, White, P. M. Jr., Petrie, E. C., Shrefler, J. W., \& Taylor, M. J. (2016). Sugarcane bagasse ash as a seedling growth media component. J. of Agricultural Sci., 8(1), 1-7. https://doi.org/10.5539/jas.v8n1p1

Webber, C. L. III, White, P. M. Jr., Spaunhorst, D. J., \& Petrie, E. C. (2017a). Comparative performance of sugarcane bagasse and black polyethylene as mulch for squash (Cucurbita pepo L.) production. Journal of Agricultural Sci., 9(11), 1-9. https://doi.org/10.5539/jas.v9n11p1

Webber, C. L. III, White, P. M. Jr., Spaunhorst, D. J., \& Petrie, E. C. (2017b). Impact of sugarcane bagasse ash as an amendment on the physical properties, nutrient content and seedling growth of a certified organic greenhouse growing media. J. of Agricultural Sci., 9(7), 1-11. https://doi.org/10.5539/jas.v9n7p1

White, P. M., Potter, T. L., \& Lima, I. M. (2015). Sugarcane and pinewood biochar effects on activity and aerobic soil dissipation of metribuzin and pendimethalin. Industrial Crops and Products, 74, 737-744. https://doi.org/10.1016/j.indcrop.2015.04.022

Xin, L., Kondo, R., \& Sakai, K. (2002). Biodegradation of sugarcane bagasse with marine fungus Phlebia sp. MG-60. J. Wood Sci., 48(2), 159-162. https://doi.org/10.1007/BF00767294

Zandersons, J., Gravitis, J., Kokorevics, A., Zhurinsh, A., Bikovens, O., Tardenaka, A., \& Spince, B. (1999). Studies of the Brazilian sugarcane bagasse carbonisation process and products properties. Biomass and Bioenergy, 17(3), 209-219. https://doi.org/10.1016/S0961-9534(99)00042-2

\section{Copyrights}

Copyright for this article is retained by the author(s), with first publication rights granted to the journal.

This is an open-access article distributed under the terms and conditions of the Creative Commons Attribution license (http://creativecommons.org/licenses/by/4.0/). 